Technical Article

\title{
Eucalyptus globulus essential oil on the postharvest quality of 'Carola' roses
}

\author{
Elka Fabiana Aparecida Almeida ${ }^{1}$, Leandra Oliveira Santos², Ariane Castricini², João Batista Ribeiro da Silva Reis ${ }^{2}$
}

\begin{abstract}
The consumer market has been demanding quality plant products, without any contamination or chemical residues, restricting their use in postharvest. As a result, is necessary increase the development of research seeking more sustainable and economic alternatives. The objective was to identify the ideal concentration of eucalyptus essential oil to maintain postharvest quality of 'Carola' roses. At laboratory, stems of the 'Carola' roses were standardized at $35 \mathrm{~cm}$, labeled and subjected to the following doses of eucalyptus (Eucalyptus globulus) essential oil: $0.25 \% ; 0.5 \% ; 0.75 \% ; 1.0 \%$ and $1.25 \%$. Spraying with distilled water was used as a control. The experiment was conducted in a completely randomized design, in a factorial scheme consisting of two factors: six postharvest treatments and seven evaluation dates $(0,1,2,3,4,5,6$ and 7 days). Four replications were used, with two flowers each. Stems fresh mass and color of the petals were analyzed daily. In addition, the visual quality was also evaluated. The total anthocyanin content in the petals was evaluated every three days at the beginning, middle and end of the experimental period. Eucalyptus essential oil in all doses tested provided better maintenance on the postharvest quality of roses: $0.25 \%$ and $0.5 \%$ (better grades), $1.0 \%$ and $1.25 \%$ (lower hue angle) and $0.25 \%$ (higher anthocyanin content). On the 5 th day, the flower stems lost $16 \%$ of fresh mass, without signs of wilting and the assigned scores also indicated that the stems remained fit for commercialization until the fifth day (total vase life). In conclusion, eucalyptus essential oil at doses $0.25 \%, 0.50 \%, 1.0 \%$ and $1.25 \%$ is effective in maintaining the quality of 'Carola' roses for up to five days at $25^{\circ} \mathrm{C}$.
\end{abstract}

Keywords: floriculture, Rosa sp., cut flowers, sustainability.

Resumo

Óleo essencial de Eucalyptus globulus na qualidade pós-colheita de rosas 'Carola'

O mercado consumidor vem exigindo qualidade dos produtos vegetais, sem qualquer contaminação ou resíduos químicos, restringindo o uso dos mesmos na pós-colheita. Em decorrência disso, é necessário aumentar o desenvolvimento de pesquisas que busquem alternativas, mais sustentáveis e econômicas. O objetivo foi identificar a concentração ideal de óleo essencial de eucalipto para a manutenção da qualidade pós-colheita de rosas 'Carola'. Foram utilizadas rosas cultivar Carola, em que, no laboratório, tiveram suas hastes padronizadas em $35 \mathrm{~cm}$, etiquetadas e submetidas às seguintes doses de óleo essencial de eucalipto (Eucalyptus globulus): $0,25 \% ; 0,5 \% ; 0,75 \% ; 1,0 \%$ e $1,25 \%$. Como controle foi realizado a pulverização com água destilada. O experimento foi conduzido em delineamento inteiramente casualizado, em esquema fatorial composto por dois fatores: seis tratamentos pós-colheita e sete datas de avaliação $(0,1$, 2, 3, 4, 5, 6 e 7 dias). Foram utilizadas quatro repetições, com duas flores cada uma. As avaliações foram realizadas diariamente, analisando-se os parâmetros de massa fresca das hastes florais e coloração das pétalas. Além disso, avaliou-se a qualidade visual, determinada de acordo com uma escala de notas. O teor de antocianinas totais nas pétalas foi avaliado a cada três dias, no início, meio e fim do período experimental. O óleo essencial de eucalipto em todas as doses testadas proporcionou melhor manutenção da qualidade pós-colheita de rosas: $0,25 \%$ e $0,5 \%$ (melhores notas), 1,0\% e 1,25\% (menor ângulo hue) e $0,25 \%$ (maior teor de antocianina). Ao $5^{\circ}$ dia as hastes florais perderam $16 \%$ de massa fresca sem que houvesse sinais de murchamento e as notas atribuídas também indicaram que as hastes permaneceram aptas para a comercialização até o quinto dia (vida de vaso total). Como conclusão, o óleo essencial de eucalipto nas doses $0,25 \%, 0,50 \%, 1,0 \%$ e $1,25 \%$ é eficiente na manutenção da qualidade de rosas 'Carola' por até cinco dias a $25^{\circ} \mathrm{C}$.

Palavras-chave: floricultura, Rosa sp., flor de corte, sustentabilidade.

\footnotetext{
${ }^{1}$ Universidade Federal de Minas Gerais, Instituto de Ciências Agrárias, Agronomia, Montes Claros-MG, Brazil

*Corresponding author: elkaflori@hotmail.com

${ }^{2}$ Empresa de Pesquisa Agropecuária de Minas Gerais (EPAMIG Norte), Nova Porteirinha-MG, Brazil
}

Received Dec 17, 2019 | Accepted Apr 14, 2020| Available online May 6, 2020

Licensed by CC BY 4.0

https://doi.org/10.1590/2447-536X.v26i2.2122

Area Editor: Gláucia Moraes Dias 


\section{Introduction}

Rose is the most commercially important cut flower in the world and, due to its susceptibility to various pests and diseases; one of the routine procedures of growers is spraying with toxic pesticides after harvest (Almeida et al., 2014). However, it is necessary to look for solutions to replace these pesticides, as they are harmful to the environment, can cause human intoxication and ultimately can become obsolete in light of pathogens' resistance. Feng and Zeng (2007) report other negative effects of postharvest application of toxic pesticides such as carcinogenicity, teratogenicity, environmental pollution and other side effects in humans. According to these authors, essential oils have both ecological and sustainable fungicidal properties and, therefore, they are an excellent possibility for replacement of toxic products in the postharvest of roses.

Research aiming alternative control of pests and diseases through the use of essential oils, plant extracts and other alternative solutions, has been considerably increased in recent years and revealed their potential to control plant pathogens (Fonseca et al., 2015) and increase the postharvest durability of roses (Manfredini et al., 2017a; Manfredini et al., 2017b), torch ginger (Mattos et al., 2017; Mattos et al., 2018) and gerbera (Maia et al., 2019). Plants have several substances derived from secondary metabolism, many of them with either fungicidal or fungistatic potential, which are to be studied for direct use by the grower, as well as to serve as raw material for the formulation of new products (Garcia et al., 2012).

For other horticultural products, it has already been possible to prove the efficiency of essential oils as a substitute for other conventional products. According to Vilaplana et al. (2018), thyme essential oil can be used on postharvest of banana to efficiently control of anthracnose (Colletotrichum musae).

Essential oils contain energy substrates, basic preservatives such as biocides, and auxiliary preservatives, which can be acidifying agents or anti-ethylene agents. These oils can be applied to flowers in multiple points of the distribution chain, from the producer to the wholesaler, the florist and by the end consumer.

The biological activity of essential oils and their constituents may act as fungistatic and/or fungicidal agents, depending on the used concentrations. The same oil may be active against a broad spectrum of microorganism species, but minimum inhibitory concentrations (MIC) may vary (Antunes and Cavacob, 2010). Overdosing can give phytotoxicity effects, as noted by Manfredini et al. (2017a) on rose. According to these authors, the application of lemongrass essential oil at $1 \%$ caused burns on petals.

The consumer market demands high quality plant products, without any contamination or chemical residues, restricting the use of conventional pesticides in postharvest. Thus, it is necessary the development of research seeking more sustainable and economical alternatives, and essential oils have great potential to replace conventional products. The objective of this study was to identify the ideal concentration of eucalyptus essential oil to maintain postharvest quality of 'Carola' roses.

\section{Material and Methods}

'Carola' roses were purchased from a commercial grower and transported to the laboratory immediately after harvest in a refrigerated vehicle $\left(8^{\circ} \mathrm{C}\right)$ with the stem base immersed in water (15-hour drive). Upon arrival, the flower stems were standardized at $35 \mathrm{~cm}$, labeled and subjected to the following doses of eucalyptus (Eucalyptus globulus) essential oil: $0.25 \% ; 0.5 \% ; 0.75 \% ; 1.0 \%, 1.25 \%$ and distilled water as a control.

The eucalyptus essential oil was diluted with distilled water with $0.02 \%$ Tween 20 . The flower buds were sprayed with the solution prepared according to each treatment and each bud received $4 \mathrm{~mL}$ of solution.

Subsequently, the flower stem bases were placed in transparent plastic pots containing $2 \mathrm{~L}$ of tap water and kept at $25{ }^{\circ} \mathrm{C}$. The experiment was conducted in a completely randomized design, in a factorial scheme consisting of two factors: six postharvest treatments and seven evaluation dates $(0,1,2,3,4,5,6$ and 7 days). Four replications were used, with two flowers each.

The evaluations were carried out daily, analyzing the fresh mass of the flower stems and color of the petals. In addition, visual quality was evaluated, determined according to a score scale, being 3: excellent overall appearance, perfect for commercialization, turgid and without spots; score 2: good overall appearance, flower bud with scarce spots on petals edges, but still with commercial quality; score 1: poor overall appearance, senescence and/ or stained flower bud, not suitable for commercialization.

Flowers were weighed daily with a precision scale to obtain their fresh mass, and the variation of it over time was calculated by the difference in the initial weight by the weight obtained each day of evaluation.

Color was determined using a Minolta CR 400 colorimeter. Readings were taken on the four replicates of each treatment, each containing two flowers and performed in the middle part of external petals of the roses.

The total anthocyanin content in the petals was evaluated every three days, at the beginning, middle and final of the experimental period, using four replications, each consisting of a flower bud. Extraction and quantification (single $\mathrm{pH}$ ) of the pigments was performed according to Teixeira et al. (2008).

The total anthocyanin (AntT) content was calculated as a result expressed in $\mathrm{mg} 100 \mathrm{~g}^{-1}$ petals, as follows:

$\operatorname{AntT}(\mathrm{mg} / 100 \mathrm{~g}$ petal $)=\frac{\text { DO } \times \text { VEC } \times \text { VED } \times 1000}{\text { Valq } \times \mathrm{m} \times 982}$

Where, DO: Optical density of the diluted extract

(absorbance reading)

VEC: Total volume of concentrated extract

VED: Total volume of diluted extract

Valq: Aliquot volume used for the dilution of concentrated extract

m: Sample mass 
The data was subjected to analysis of variance by the $\mathrm{F}$ test and the means were compared using the Tukey and Scott-Knott test at 5\% probability.

\section{Results and Discussion}

Eucalyptus essential oil applied in the postharvest is efficient to maintain the quality of 'Carola' roses. Regarding the quality characteristics of 'Carola' roses evaluated by scores, it is verified that the treatments with eucalyptus essential oil, at doses of $0.25 \%$ and $0.50 \%$, provided better maintenance of flower stem quality (Table 1).
The use of oil also provided a favorable effect on the color of the petals. The hue angle was influenced by the treatments, and the concentrations $1.0 \%$ and $1.25 \%$ yielded the lowest value (Table 2). As a result, roses treated with these concentrations of eucalyptus oil were shown with more intense red petals. This result is confirmed by Pietro et al. (2012), in which the best maintenance of the red color, expressed by the color angle, was obtained in the treatment with ginger essential oil spraying, while flowers treated with distilled water expressed the largest reduction in this parameter.

Table 1. Visual quality assessed by scores assigned to the flower stems of 'Carola' roses treated with doses of eucalyptus essential oil and stored at $25^{\circ} \mathrm{C}$ for 7 days.

\begin{tabular}{|c|c|}
\hline Doses of eucalyptus essential oil & Means \\
\hline $0.00 \%$ & $2.39 \pm 1.69 \mathrm{~b}$ \\
\hline $0.25 \%$ & $2.64 \pm 1.69 \mathrm{a}$ \\
\hline $0.50 \%$ & $2.64 \pm 1.51 \mathrm{a}$ \\
\hline $0.75 \%$ & $2.42 \pm 1.18 \mathrm{~b}$ \\
\hline $1.00 \%$ & $2.46 \pm 1.03 \mathrm{~b}$ \\
\hline $1.25 \%$ & $2.42 \pm 0.83 \mathrm{~b}$ \\
\hline
\end{tabular}

Means followed by the same letter in the column do not differ at $5 \%$ by the Scott-knott test. Score 3: excellent overall appearance, perfect for commercialization, turgid, showy and without spots; score 2: good overall appearance, flower bud with some altered characteristic, but still with commercial quality; score 1: poor overall appearance, senescence and/or stained flower bud, not suitable for commercialization.

Table 2. Mean values of coloring and fresh mass loss of 'Carola' roses treated with doses of eucalyptus essential oil.

\begin{tabular}{|c|c|c|c|c|}
\hline \multirow{2}{*}{ Doses } & \multicolumn{4}{|c|}{ Dependent Variables } \\
\cline { 2 - 4 } & Luminosity & Chromaticity & Hue angle & Fresh mass loss \\
\hline $0.00 \%$ & $30.46 \pm 0.00 \mathrm{a}$ & $49.19 \pm 0.00 \mathrm{a}$ & $22.47 \pm 0.00 \mathrm{ab}$ & $13.15 \pm 0.00 \mathrm{a}$ \\
\hline $0.25 \%$ & $30.90 \pm 21.67 \mathrm{a}$ & $50.30 \pm 35.39 \mathrm{a}$ & $22.85 \pm 15.98 \mathrm{a}$ & $12.55 \pm 8.70 \mathrm{a}$ \\
\hline $0.50 \%$ & $31.20 \pm 21.71 \mathrm{a}$ & $49.74 \pm 34.82 \mathrm{a}$ & $22.45 \pm 15.52 \mathrm{ab}$ & $13.79 \pm 9.40 \mathrm{a}$ \\
\hline $0.75 \%$ & $30.35 \pm 20.93 \mathrm{a}$ & $48.64 \pm 33.86 \mathrm{a}$ & $22.88 \pm 15.65 \mathrm{a}$ & $11.46 \pm 7.57 \mathrm{a}$ \\
\hline $1.00 \%$ & $30.84 \pm 21.10 \mathrm{a}$ & $49.96 \pm 34.62 \mathrm{a}$ & $22.09 \pm 14.91 \mathrm{~b}$ & $13.61 \pm 8.92 \mathrm{a}$ \\
\hline $1.25 \%$ & $31.44 \pm 21.35 \mathrm{a}$ & $49.62 \pm 34.20 \mathrm{a}$ & $22.07 \pm 14.72 \mathrm{~b}$ & $14.96 \pm 9.69 \mathrm{a}$ \\
\hline
\end{tabular}

Means followed by the same letter in the column do not differ at $5 \%$ by the Tukey test. 
The variables luminosity and chromaticity of the petals and fresh mass loss were not influenced by the treatments.

Figures 1A and 1B show an evolution of rose coloration until the third day of storage, in the variables luminosity and chromaticity, presenting an intense and bright coloration. From the fourth day onwards, it is possible to notice a continuous reduction in these variables, especially on the seventh day of storage, with a more pronounced reduction, probably due to the prominent senescence.

It can be seen from Figure $1 \mathrm{C}$ that, on the second day of storage, the roses were more intense red color and, from the third day, there was an increase in the hue angle with consequent variations in the nuance of the red color. However, the angular range remains in the red color range, whose nuances are regulated by trends in luminosity and chromaticity.
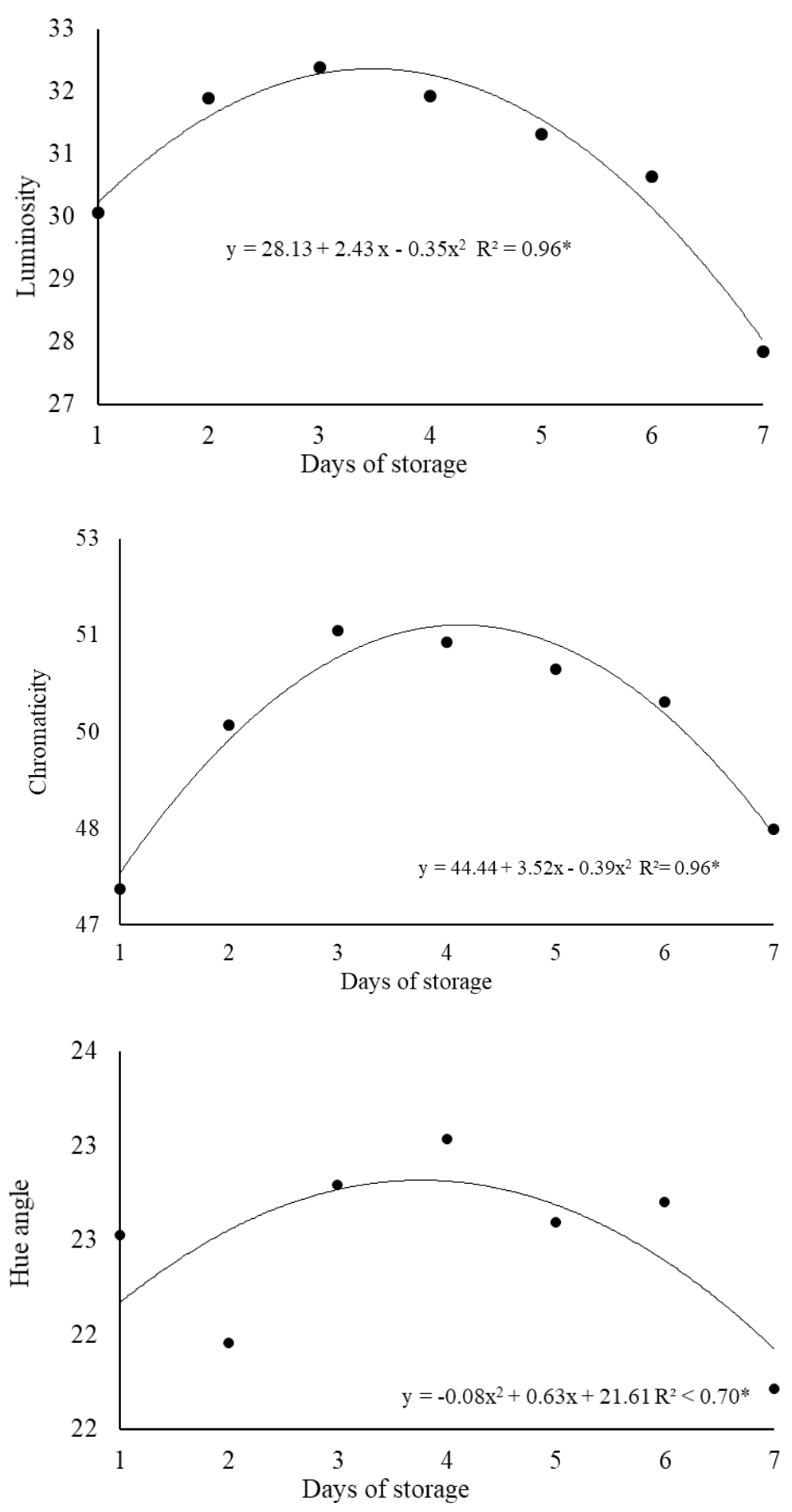

Figure 1. Luminosity, chromaticity and hue angle of 'Carola' rose petals treated with doses of eucalyptus essential oil and stored at $25^{\circ} \mathrm{C}$ for 7 days. 
The total anthocyanin content of the petals did not differ over the three sampled days; the differences occurred due to the effects of the treatments (Table 3). With the application of $0.25 \%$ essential oil, the petals presented higher anthocyanin content than those treated with $1.0 \%$. This higher content probably positively influenced the visual quality of the roses. It was not observed significant differences between the remainder treatments. The mean values found in this study are similar to those verified by Prata et al. (2017) for 'Carola' roses.

The anthocyanin levels verified in this study are similar to those found by Kuskoski et al. (2006) in blackberry and grape pulp (41.8 and $30.9 \mathrm{mg} 100 \mathrm{gg}^{-1}$, respectively) and higher than those of açaí, guava

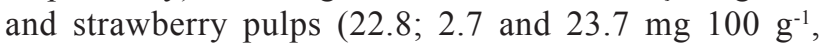
respectively).

Table 3. Anthocyanin content ( $\left.\mathrm{mg} 100 \mathrm{~g}^{-1}\right)$ of 'Carola' rose petals treated with doses of eucalyptus essential oil and stored at $25^{\circ} \mathrm{C}$ for 7 days.

\begin{tabular}{|c|c|}
\hline Doses & Means \\
\hline $0.00 \%$ & $42.79 \pm 4.06 \mathrm{ab}$ \\
\hline $0.25 \%$ & $45.49 \pm 10.78 \mathrm{a}$ \\
\hline $0.50 \%$ & $41.84 \pm 0.74 \mathrm{ab}$ \\
\hline $0.75 \%$ & $39.71 \pm 1.34 \mathrm{ab}$ \\
\hline $1.00 \%$ & $39.40 \pm 0.73 \mathrm{~b}$ \\
\hline $1.25 \%$ & $42.34 \pm 2.44 \mathrm{ab}$ \\
\hline
\end{tabular}

Means followed by the same letter in the column do not differ at $5 \%$ by the Tukey test.

Fresh weight reduction data, in Figure 2, show loss of turgescence throughout the experiment. According to Pietro el al. (2012), the loss of fresh mass occurred in the treatments with ginger, peppermint and propolis essential oils. However, the intensity of this loss was more pronounced in the treatment with distilled water, when compared to the other treatments. Fresh weight loss can be caused by transpiration, decreased water absorption due to stem obstruction by microorganisms or genetically determined factors. On the 5 th day, the flower stems lost $16 \%$ of fresh mass without signs of wilting and the assigned scores also indicated that the stems remained fit for consumption until the fifth day.
It is noteworthy that water deficiency in the organism accelerates senescence (Mayak, 1987) and, according to Nowak and Rudnick (1990), cut flowers that lose 10-15\% of their fresh mass are commonly wilted. The same was not observed in this study in which, on the 5th day of storage, the stems lost $16 \%$ of fresh mass and still had no wilting signs.

Roses sprayed with eucalyptus oil maintained their visual quality characteristics that correspond to vase life until the fifth day of storage, when they scored 2.66 (Table 4).

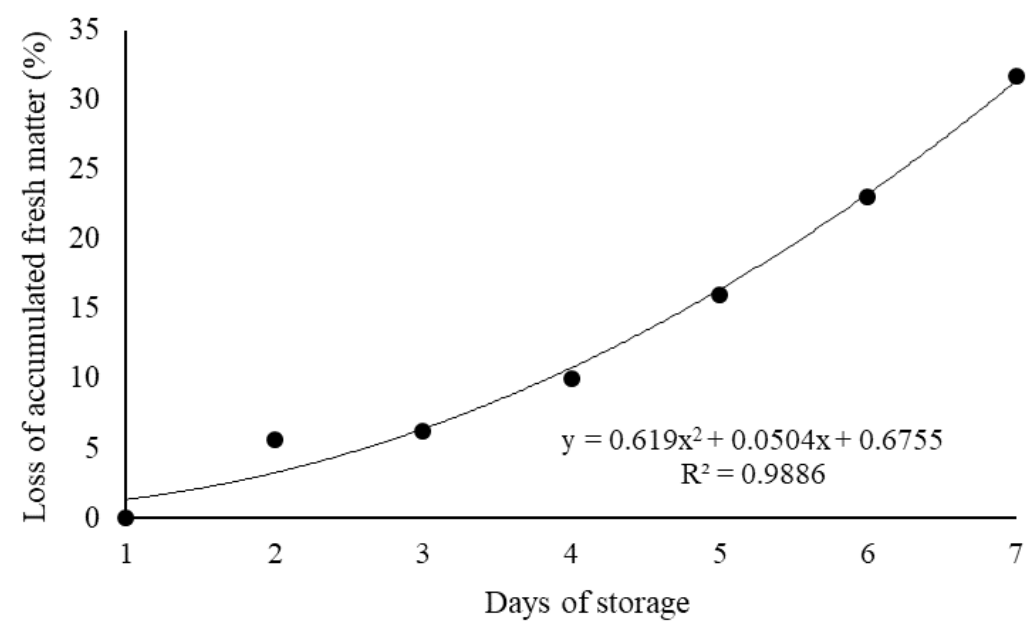

Figure 2. Loss of accumulated fresh mass of 'Carola' flower stems treated with doses of eucalyptus essential oil and stored at $25^{\circ} \mathrm{C}$ for 7 days. 
Table 4. Visual quality assessed by scores assigned to 'Carola' flower stems treated with doses of eucalyptus essential oil and stored at $25^{\circ} \mathrm{C}$ for 7 days.

\begin{tabular}{|c|c|}
\hline Days of storage & Means \\
\hline $1 \mathrm{st}$ & $3.00 \pm 1.41 \mathrm{a}$ \\
\hline 2nd & $3.00 \pm 1.41 \mathrm{a}$ \\
\hline $3 \mathrm{rd}$ & $3.00 \pm 0.00 \mathrm{a}$ \\
\hline 4 th & $2.70 \pm 0.92 \mathrm{~b}$ \\
\hline 5 th & $2.66 \pm 1.65 \mathrm{~b}$ \\
\hline 6 th & $1.87 \pm 2.92 \mathrm{c}$ \\
\hline 7 th & $1.25 \pm 4.07 \mathrm{~d}$ \\
\hline
\end{tabular}

Means followed by the same letter in the column do not differ at $5 \%$ by the Scott-knott test.

Score 3: excellent overall appearance, perfect for commercialization, turgid, showy and without spots; score 2: good overall appearance, flower bud with some altered characteristic, but still with commercial quality; score 1: poor overall appearance, senescence and/or stained flower bud, not suitable for commercialization.

The vase life of roses was not increased by treatments, but the eucalyptus improved their quality confirmed by hue angle, anthocyanin content and grading. Also, no toxicity was observed in 'Carola' rose petals, as well as in the whole flower, which is an advantage for eucalyptus essential oil. Essential oils of oregano, sagebrush and mint have already been made for fruits such as grapes and peaches and did not cause any phytotoxicity (Elshafier et al., 2015; Sonker et al., 2015, Guerra et al., 2016). On the contrary, Manfredini et al. (2017b) found that $1 \%$ lemongrass essential oil caused 'Avalanche' rose petals injuries, but noted that eucalyptus or peppermint essential oil at $1 \%$ favors the maintenance of flower quality.

These results obtained with 'Carola' roses corroborate those obtained by Manfredini et al. (2017b). According to these authors, cold-chamber storage strategies in combination with the use of eucalyptus or mint essential oils, both at $1 \%$, enable longer durability of 'Avalanche' roses. Thus, it can be inferred that eucalyptus essential oil is a product with great potential to be used pure or in the composition of flower preservatives for roses, since two important cultivars of great economic value had excellent response when submitted to the application of this alternative product.

\section{Conclusions}

Eucalyptus essential oil at doses $0.25 \%, 0.50 \%, 1.0 \%$ and $1.25 \%$ is effective in maintaining the quality of 'Carola' roses for up to five days at $25{ }^{\circ} \mathrm{C}$, which corresponds to vase life.

Variation in the intensity and brightness of the red color of petals, loss of fresh mass and reduction of visual quality was observed during storage.

\section{Acknowledgements}

CNPq, FAPEMIG and CAPES/FINEP provided the financial support to conduct this research.

\section{Author Contribution}

E.F.A.A. ${ }^{0000-0002-0800-8379}$ : experimental planning, conduction and evaluation of the experiment, writing of the manuscript; L.O.S. 0000-0003-1737-2807: conduction and evaluation of the experiment, tabulation and statistical analysis of data, writing

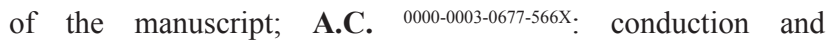
evaluation of the experiment and writing of the manuscript; J.B.R.S.R. ${ }^{0000-0001-5677-605 x}$ : writing and editing of the manuscript.

\section{References}

ALMEIDA, E.F.A.; PIVETTA, K.F.L.; PAIVA, P.D.O.; ICHINOSE, J.G.S.; GIMENES, R.; REIS, S.N.; CARVALHO, L.M.; RIBEIRO, M.N. O. Rosa. In: PAIVA, P.D.O.; ALMEIDA, E.F.A. Produção de Flores de Corte. Lavras: Editora da UFLA, 2014. p. 607-708. v.2.

ANTUNES, M.D.C.; CAVACOB, A. The use of essential oils for postharvest decay control. A review. Flavour Fragrance Journal, v.25, p.351-366, 2010.

ELSHAFIE, H.S.; MANCINI, E.; SAKR, S.; MARTINO, L.; MATTIA, C.A.; FEO, V.; CAMELE, I. Antifungal activity of some constituents of Origanum vulgare L. essential oil against postharvest disease of peach fruit. Journal of Medicinal Food, v.18, n.8, p.929-934, 2015. 
FENG, W.; ZHENG, X. Essential oils to control Alternaria alternata in vitro and in vivo. Food Control, n.18, p.11261130, 2007.

FONSECA, M.C.M.; LEHNER, M.S.; GONÇALVES, M.G.; PAULA JÚNIOR, T.J.; SILVA, A.F.; BONFIM, F.P.G.; PRADO, A.L. Potencial de óleos essenciais de plantas medicinais no controle de fitopatógenos. Revista Brasileira de Plantas Medicinais, v.17, n.1, p.45-50, 2015.

GARCIA, R.A.; JULIATTI, F.C.; BARBOSA, K.A.G.; CASSEMIRO, T.A. Atividade antifúngica de óleos e extratos vegetais sobre Sclerotinia sclerotiorum. Bioscience Journal, v.28, n.1, p.48-57, 2012.

GERRA, I.C.D.; OLIVEIRA, P.D.L.; SANTOS, M.M.F.; LÚCIO, A.S.S.C; TAVARES, J.F.; BARBOSA-FILHO, J.M.; MADRUGA, M.S.; SOUZA, E.L. The effects of composite coatings containing chitosan and Mentha (piperita L. or x villosa Huds) essential oil on postharvest mold occurrence and quality of table grape cv. Isabella. Innovative Food Science and Emerging Technologies, v.34, p.112-121, 2016.

KUSKOSKI, E.M.; ASUERO, A.G.; MORALES, M.T.; FETT, R. Frutos tropicais silvestres e polpas de frutas congeladas: atividade antioxidante, polifenóis e antocianinas. Ciência Rural, v.36, n.4, p.1283-1287, 2006.

MAIA, R.K.M.; SILVA, E.A.; ALVES, R.M.; MORAIS, M.A.S.; VIEIRA, M.R.S.; SILVA, L.F.; SIMÕES, R.F.J.; FONSECA, K.S.; SIMÕES, A.N.N. Ethanol and citric acid improve longevity in Gerbera cv. Mistique. Ornamental Horticulture, v.25, n.2, p.109-118, 2019.

MANFREDINI, G.M. PAIVA, P.D.O; ALMEIDA, E.F.A.; REIS, M.V.R.; MAIA, M.O. Storage and methil jasmonate in postharvest conservation of roses cv. Avalanche. Ornamental Horticulture, v.23, n.2, p.207-211, 2017.

MANFREDINI, G.M.; PAIVA, P.D.O.; ALMEIDA, E.F.A.; NASCIMENTO, A.M.P.; SALES, T.S.; SANTOS, L.O. Postharvest quality of essential oil treated roses. Ornamental Horticulture, v.23, n.2, p.192-199, 2017.
MATTOS, D.G.; PAIVA, P.D.O.; ELIAS, H.H.S.; VILAS BOAS, E.V.B.; RODRIGUES, L.F.; LAGO, R.C. Starch and total soluble sugar content in torch ginger postharvest. Ornamental Horticulture, v.23, n.4, p.435-442, 2018.

MATTOS, D.G.; PAIVA, P.D.O.; NERY, F.C.; VALE, R.P.; SARTO, M.T.; LUZ, C.A. Water relations in post-harvest torch ginger affected by harvest point and carnaúba wax. Postharvest Biology and Technology, v.127, p.35-43, 2017.

MAYAK, S. Senescence of cut flowers. HortScience, v.22, n.5, p.863-868, 1987.

NOWAK, J.; RUDNICK, R.M. Postharvest handling and storage of cut flowers, florist greens, and potted plant. Portland: Timber Press, 1990. 210p.

PIETRO, J.; MATTIUZ, B.H.; MATTIUZ, C.F.M.; RODRIGUES, T.J.D. Qualidade de rosas de corte tratadas com produtos naturais. Ciência Rural, v.42, n.10, p.17811788, 2012.

PRATA, G.G.B.; SOUZA, K.O.; LOPES, M.M.A.; OLIVEIRA, L.S.; ARAGAO, F.A.S.; ALVES, R.E. SILVA, S.M. Nutritional characterization, bioactive compounds and antioxidante activity of brazilian roses (Rosa spp). Journal of Agricultural Science and Technology, v.19, p.929-94, 2017.

SONKER, N.; PANDEY, A.K.; SINGH, P. Efficiency of Artemisia nilagirica (Clarke) Pamp. essential oil as a mycotoxicant against postharvest mycobiota of table grapes. Journal of the Science of Food and Agriculture, v.95, n.9, p.1932-1939, 2015.

TEIXEIRA, L.N.; STRINGHETA, P.C.; OLIVEIRA, F.A. Comparação de métodos para quantificação de antocianinas. Revistas Ceres, v.55, n.4, p.297-304, 2008.

VILAPLANA, R.; PAZMIÑO, L.; VALENCIACHAMORRO, S. Control of anthracnose, caused by Colletotrichum musae, on postharvest organic banana by thyme oil. Postharvest Biology and Technology, v.138, n. 1, p.56-63, 2018. 